\title{
Development of teaching materials based on learning video using movavi education set at Yayasan Perguruan Tunas Karya Batang Kuis
}

\author{
Mahyuddin K. M. Nasution, Marischa Elveny, Sri Melvani Hardi, Ivan Jaya ${ }^{*}$ Faculty of \\ Computer Science and Information Technology, Universitas Sumatera Utara, \\ Medan, Indonesia \\ *Email: ivanjaya@usu.ac.id
}

\begin{abstract}
The COVID-19 pandemic that has recently hit various countries including Indonesia has resulted in major changes in various fields, including in the development of the education sector. The teaching and learning process has turned from face-to-face into an online method. However, there are several obstacles experienced by schools that implement an online learning system, one of them was the ability of teachers who do not understand various learning application platforms. In addition, the material provided by the teacher is not maximally acceptable to students because most teachers provide learning material from the pages of textbooks or teacher writings (scans, photos, or presentation files). For this reason, it is necessary to have variations in the provision of teaching materials to students by making interesting and creative learning videos using the Movavi Education Set. With learning videos, students can do lessons at home, repeat it, and can ask the teacher some points from it if they don't understand. By using Movavi Education Set, teachers are also free to be creative in making learning videos that can be shared through commonly used communication applications such as e-mail, WhatsApp, line, google classroom and other applications.
\end{abstract}

Keyword: teaching materials, learning video, movavi education set

\begin{abstract}
Abstrak
Pandemi COVID-19 yang belakangan ini melanda berbagai negara termasuk Indonesia telah mengakibatkan perubahan besar di berbagai bidang, termasuk dalam pembangunan sektor pendidikan. Proses belajar mengajar telah berubah dari tatap muka menjadi metode online. Namun terdapat beberapa kendala yang dialami sekolah yang menerapkan sistem pembelajaran online, salah satunya adalah kemampuan guru yang kurang memahami berbagai platform aplikasi pembelajaran. Selain itu, materi yang diberikan guru kurang dapat diterima secara maksimal oleh siswa karena sebagian besar guru memberikan materi pembelajaran dari halaman buku teks atau tulisan guru (scan, foto, atau file presentasi). Untuk itu perlu adanya variasi dalam pemberian bahan ajar kepada siswa dengan membuat video pembelajaran yang menarik dan kreatif dengan menggunakan Movavi Education Set. Dengan video pembelajaran, siswa dapat melakukan pelajaran di rumah, mengulanginya, dan dapat menanyakan beberapa poin kepada guru jika mereka tidak mengerti. Dengan menggunakan Movavi Education Set, guru juga bebas berkreasi dalam membuat video pembelajaran yang dapat dibagikan melalui aplikasi komunikasi yang biasa digunakan seperti e-mail, whatsapp, line, google classroom dan aplikasi lainnya.
\end{abstract}

Kata Kunci: bahan ajar, video pembelajaran, movavi education set

\section{PENDAHULUAN (INTRODUCTION)}

Beberapa bulan belakangan ini seluruh negara termasuk indonesia mengalami kepanikan akibat adanya wabah pandemi penyebaran virus Corona (Covid-19), beragam kepanikan terjadi di berbagai sektor bidang termasuk dalam bidang pendidikan. Pembelajaran yang normalnya dilakukan dengan tatap muka di kelas berubah menjadi pembelajaran dengan menggunakan pembelajaran daring (online) kombinasi. 
Pembelajaran daring kombinasi adalah bentuk pembelajaran yang memadukan antara pembelajaran secara tatap muka dengan pembelajaran daring (online) dan atau e-learning yang bertujuan untuk memudahkan dalam mendapatkan pembelajaran dengan pengajar secara online (Rimbarizki, 2017). Pembelajaran secara daring dinilai lebih menantang dan menarik daripada pembelajaran secara tatap muka (Kuntarto, 2017). Dengan menerapkan teknologi informasi dan komunikasi secara tepat guna, upaya peristiwa belajar dapat dioptimalkan (Chaeruman, 2018). Terkait dengan pembelajaran daring, beberapa perusahaan telekomunikasi Indonesia sudah mulai melakukan kerja sama dengan berbagai platform pembelajaran daring untuk mendukung kegiatan pembelajaran model baru ini. Bagi sekolah sekolah yang terbiasa menggunakan teknologi informasi sebagai alat bantu pembelajaran di kelas mungkin tidak akan menjadi persoalan. Namun bagaimana dengan sekolah sekolah yang tidak terbiasa menggunakan metode pembelajaran daring dikarenakan berbagai aspek yang menghambat.

Salah satu aspek yang menghambat dalam pembelajaran daring adalah kurangnya pemahaman para guru terhadap penggunaan platform pembelajaran daring. Para guru melakukan pembelajaran daring menggunakan aplikasi grup whatsapp dimana materi dan tugas dibagikan melalui foto atau soft-copy (berkas presentasi), sehingga cenderung monoton dan kurang menarik minat murid untuk belajar. Hal tersebut dialami oleh SMP dan SMK di Yayasan Pendidikan Tunas Karya yang berlokasi di Jalan Medan Batang Kuis, Bakaran Batu, Kec. Batang Kuis, Kabupaten Deli Serdang.

Yayasan Pendidikan Tunas Karya Batang Kuis (Gambar 1.1) merupakan yayasan pendidikan yang terdiri dari SMP unggulan dan reguler serta SMK yang memiliki empat program studi keahlian yaitu keuangan, manajemen perkantoran, kepariwisataan, kuliner dengan jumlah siswa sekitar 600 siswa siswi. Dari wawancara dan diskusi antara pihak mitra dengan tim pengabdian, diperoleh solusi yang ditawarkan yaitu pelatihan kepada para guru untuk pembuatan video pembelajaran yang kreatif dengan tujuan memberikan pembelajaran yang menarik dengan memanfaatkan Movavi Education Set, sehingga bisa meningkatkan kemampuan pemahaman para siswa siswi dalam memahami materi meskipun pembelajaran dilakukan di rumah. Video pembelajaran yang telah dibuat dapat dibagikan melalui media sosial ataupun aplikasi komunikasi seperti whatssapp, line dan sebagainya. Siswa dan siswi bisa belajar dengan menonton video yang telah dibuat oleh guru, memutar video secara berulang dan bisa menanyakan ke guru di bagian tertentu pada video jika masih belum jelas atau belum dipahami.
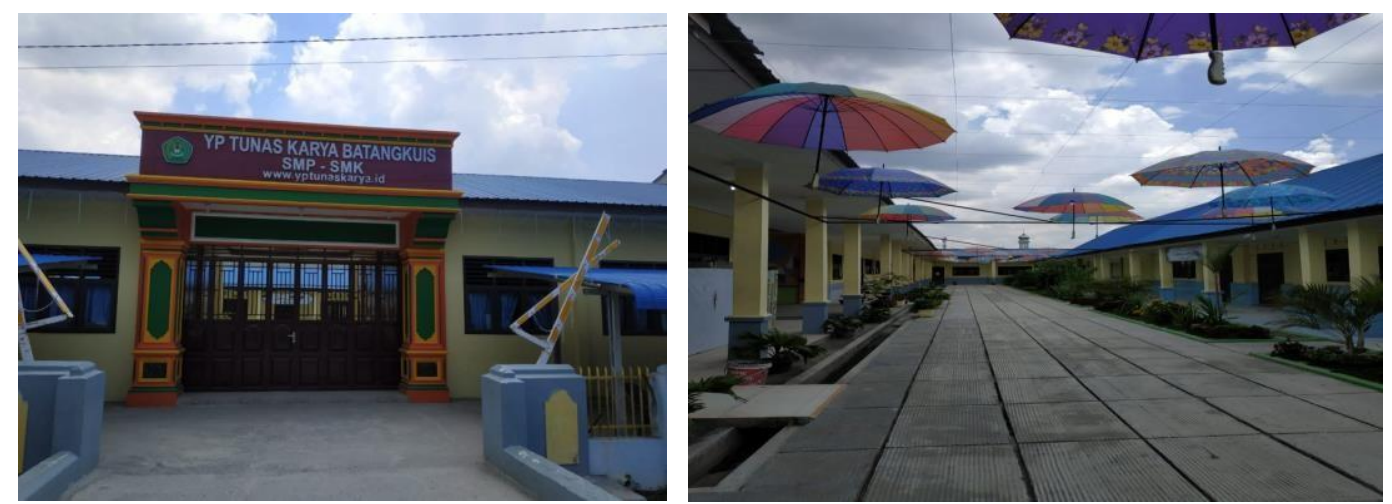

Gambar 1.1. Yayasan Perguruan Tunas Karya Batang Kuis

\section{METODE PELAKSANAAN}

Kegiatan pengabdian masyarakat ini dilaksanakan mulai bulan Juli sampai bulan Nopember 2020. Pelaksanaan dimulai dari penyusunan gambaran IPTEK yang ditransfer ke mitra yang dapat dilihat pada Gambar 2.2. 
Mahyuddin, et al Development of teaching materials based on learning video using movavi education set at Yayasan Perguruan Tunas Karya Batang Kuis

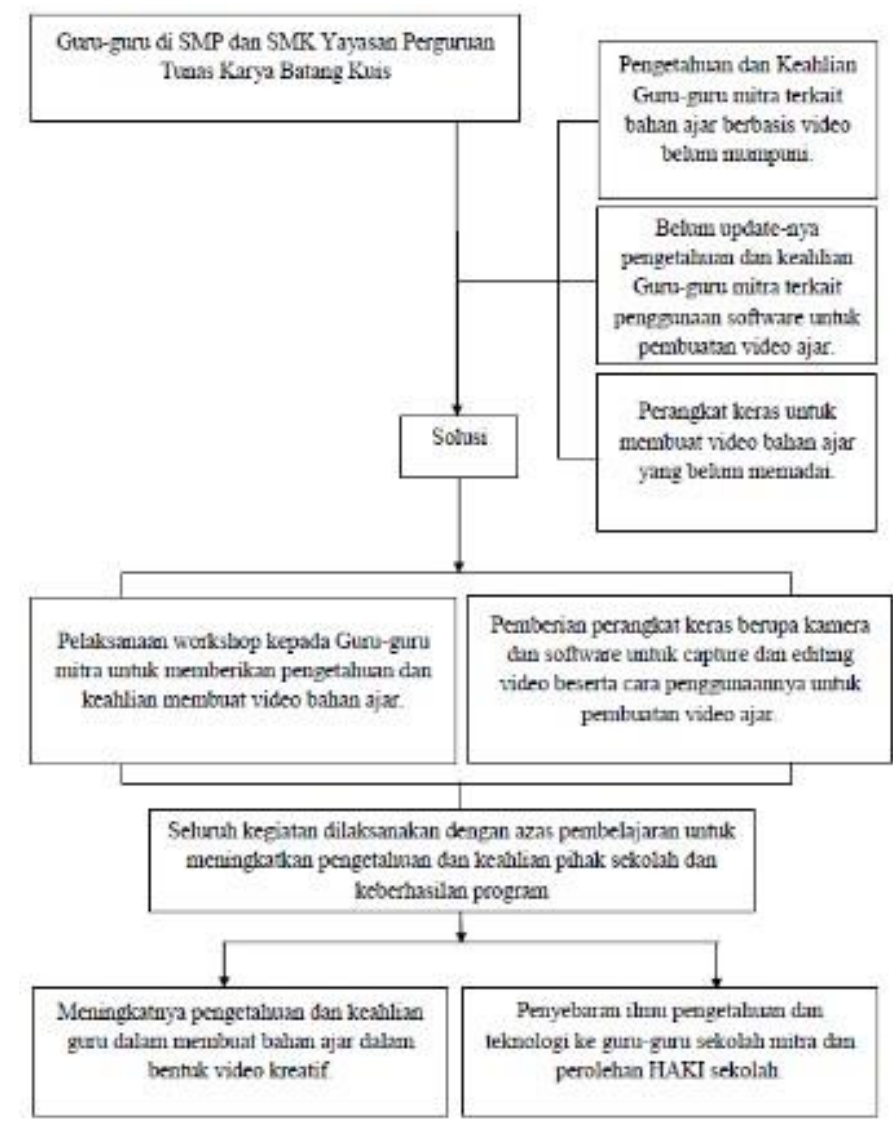

Gambar 2.2. Gambaran IPTEK yang ditransfer ke mitra

Dari gambaran IPTEK dijabarkan menjadi beberapa tahapan dalam pelaksanaan kegiatan pengabdian masyarakat diantaranya:

1. Pengenalan dan pelatihan penggunaan aplikasi Movavi Education Set kepada mitra.

Pelaksanaan kegiatan pengabdian dilakukan oleh tim pengabdian ke sekolah Yayasan Tunas Karya. Tim pengabdian terdiri dari 4 orang dosen yang dibantu 1 orang mahasiswa. Dalam pelaksanaan kegiatan pengabdian diberikan pelatihan berupa penggunaan aplikasi movavi education set sebagai alat bantu bagi para guru dalam membuat video pembelajaran. Sebelum memulai pelatihan, terlebih dahulu dilakukan serah terima barang pada pihak Sekolah Yayasan Tunas Karya (Gambar 2.3) yang diwakili oleh kepala sekolah yaitu berupa pemberian sebuah kamera Canon EOS 3000D, memori external 64 gb San Disk, serta pemberian 10 akun berlisensi movavi education set.
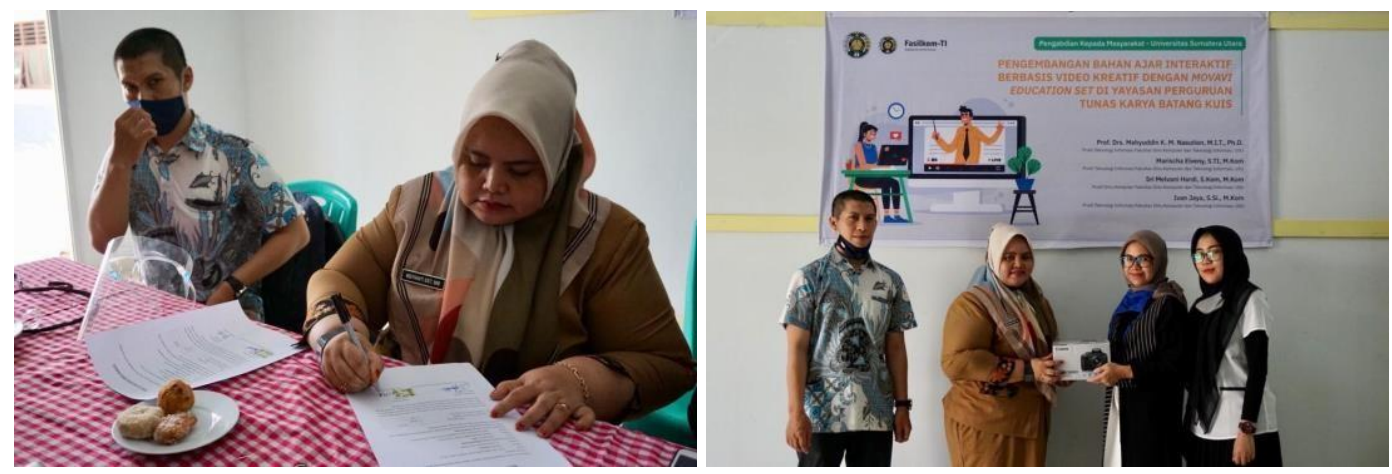

Gambar 2.3. Serah terima barang pendukung pelatihan ke mitra 
Sebelum memasuki materi pelatihan, para peserta yang terdiri dari bapak ibu guru di sekolah mitra diminta untuk mengerjakan pre test yang sudah disiapkan oleh tim berupa beberapa pertanyaan di google form untuk mengetahui kemampuan awal para peserta pelatihan mengenai topik ataupun materi yang akan disampaikan.

2. Pelatihan pembuatan video pembelajaran dan HaKI.

Pada pelatihan ini tim pengabdian memberikan pelatihan terkait editing video pembelajaran (Gambar 2.4). Para peserta pelatihan diminta untuk menginstal aplikasi movavi education set yang sudah dipersiapakan sebelumnya oleh tim pengabdian beserta panduan penggunaannya kemudian para peserta diminta membuat satu video pendek terkait materi ajar. Respon para peserta sangat antusias pada sesi ini dikarenakan para peserta pelatihan sebelumnya belum pernah menggunakan aplikasi movavi education set. Setelah pelatihan pembuatan dan editing video, tim pengabdian memberikan materi mengenai Hak Atas Kekayaan Intelektual (HaKI) antara lain menjelaskan definisi HaKI, apa saja produk yang dapat di daftarkan dan manfaat yang didapatkan apabila suatu produk didaftarkan HaKI-nya.
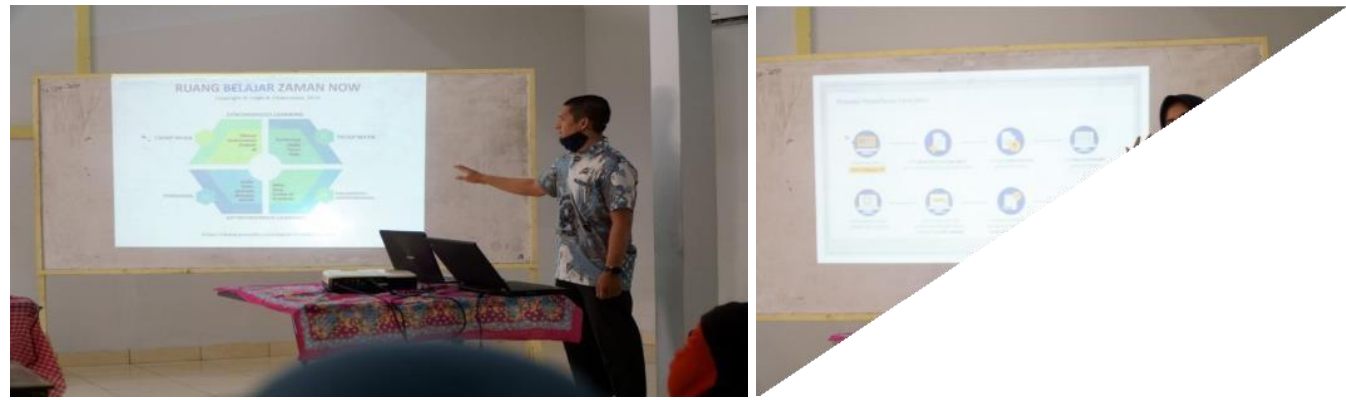

Gambar 2.4. Pelatihan Pembuatan Video Pembelajaran dan HaKI

Setelah selesai menyampaikan 3 materi pelatihan, tim pengabdian memberikan post test di akhir sesi pelatihan, untuk melihat pemahaman para peserta pelatihan terhadap materi yang diberikan apakah sudah dapat dipahami dengan baik sehingga mampu memberikan dan meningkatkan pengetahuan para peserta pelatihan.

3. Pemberian tugas kepada para guru.

Setelah pelatihan selesai diberikan, tim pengabdian memberikan tugas kepada para guru untuk menyempurnakan video pembelajaran kreatif dan tim pengabdian memberikan waktu selama 12 minggu untuk pengiriman video ke tim pengabdian melalui link google drive yang disediakan tim pengabdian. Tidak lupa tim pengabdian dan mitra melakukan sesi foto bersama untuk dokumentasi kegiatan (Gambar 2.5).

4. Pemilihan video pembelajaran terbaik.

Dari video yang dikirimkan, tim pengabdian melakukan evaluasi dan memilih 3 (tiga) video terbaik untuk pengurusan hak cipta ke Direktorat Jenderal Kekayaan Intelektual (DJKI) sehingga hak cipta tersebut dapat digunakan untuk dokumen pendukung prestasi pihak sekolah.

5. Evaluasi dan tukar pendapat.

Tim pengabdian melakukan evaluasi terhadap keseluruhan kegiatan yang dilakukan dan menerima masukan berupa saran dari mitra.

6. Mendaftarkan 3 (tiga) video pembelajaran terbaik utk didaftarkan hak cipta-nya sehingga memberikan nilai tambah bagi akreditasi sekolah.

7. Penyusunan laporan.

Tim pengabdian menyusun laporan dari pelaksanaan kegiatan pengabdian masyarakat yang telah dilakukan. Laporan ini diserahkan ke Lembaga Pengabdian Masyarakat USU mencakup keseluruhan kegiatan yang telah dilaksanakan, hasil dan luaran dari kegiatan serta umpan balik dari mitra. 


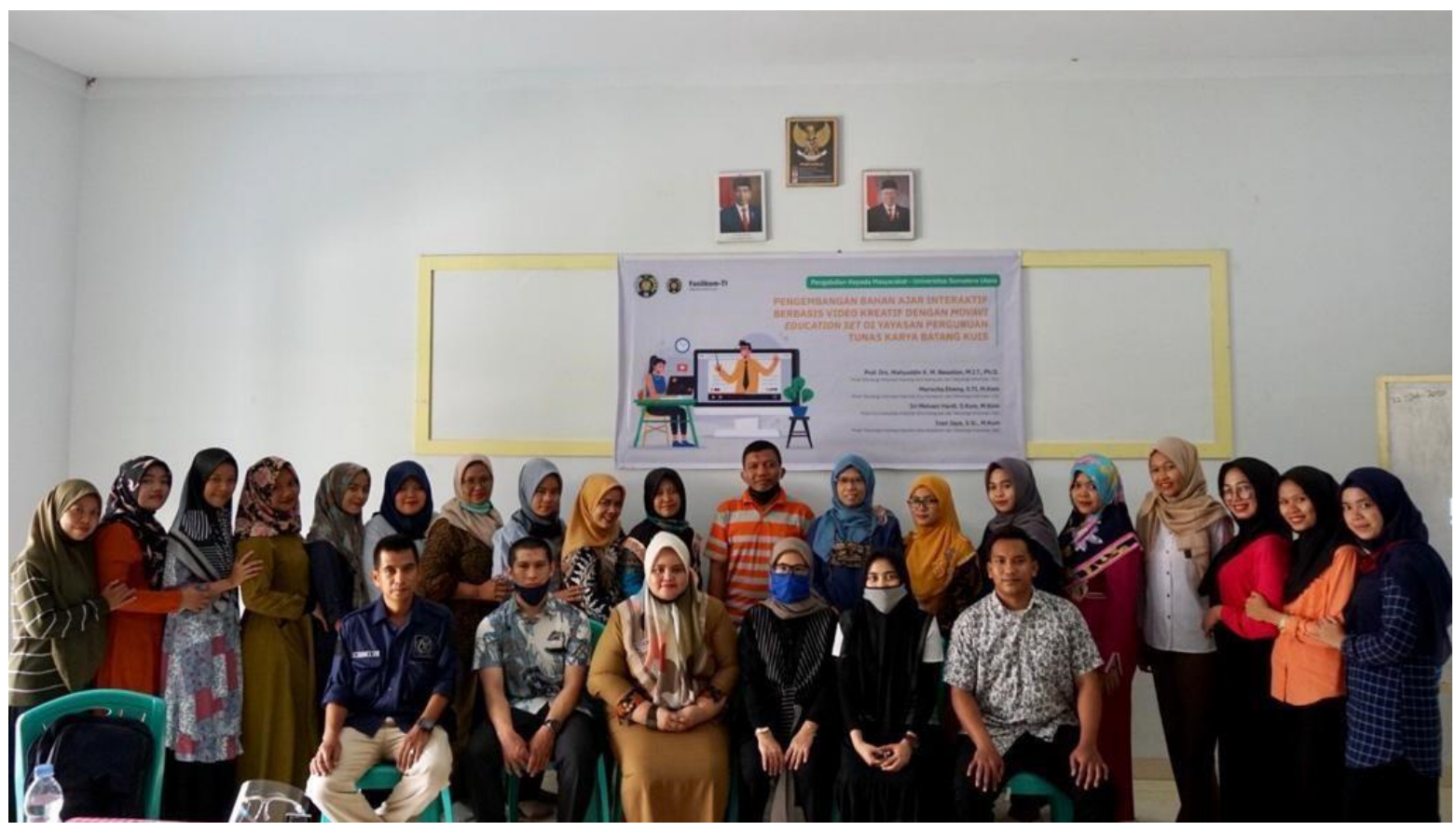

Gambar 2.5. Foto bersama tim pengabdian masyarakat dengan mitra

\section{HASIL DAN PEMBAHASAN}

Kegiatan pengabdian kepada masyarakat ini memberikan dampak positif bagi sekolah mitra yaitu penambahan ilmu pengetahuan dan keahlian pembuatan dan editing video pembelajaran para peserta pelatihan dalam hal ini adalah guru-guru di sekolah mitra terkait. Para guru dapat membuat video pembelajaran yang menarik sehingga di masa pandemi ini proses belajar mengajar bisa lebih menyenangkan dan bervariasi dengan adanya materi ajar berupa video pembelajaran.

Selain peningkatan pengetahuan para guru mitra terkait, tim pengabdian menghasilkan beberapa luaran kegiatan pengabdian diantaranya publikasi kegiatan di media online yaitu harianmedan.com, gosumut.com dan transbisnis.com yang dapat dilihat pada Gambar 3.1.

Selain luaran kegiatan berupa publikasi kegiatan di media online, luaran lainnya yaitu video kegiatan yang diunggah di media online youtube (https://youtu.be/pIC5ISsWp_E) serta sertifikat hak cipta berupa buku panduan penggunaan movavi yang menjadi luaran tambahan pada kegiatan pengabdian ini yang dapat dilihat pada Gambar 3.2.

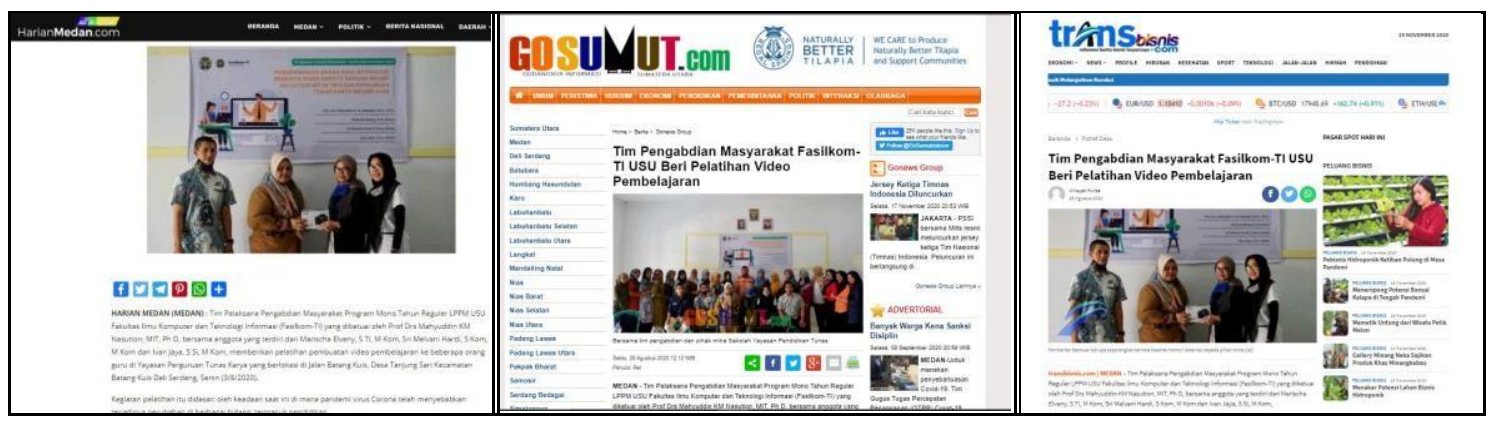

Gambar 3.1. Kegiatan pengabdian diterbitkan di media online 
Mahyuddin K. M. Nasution et. al. Development of teaching materials based on learning video

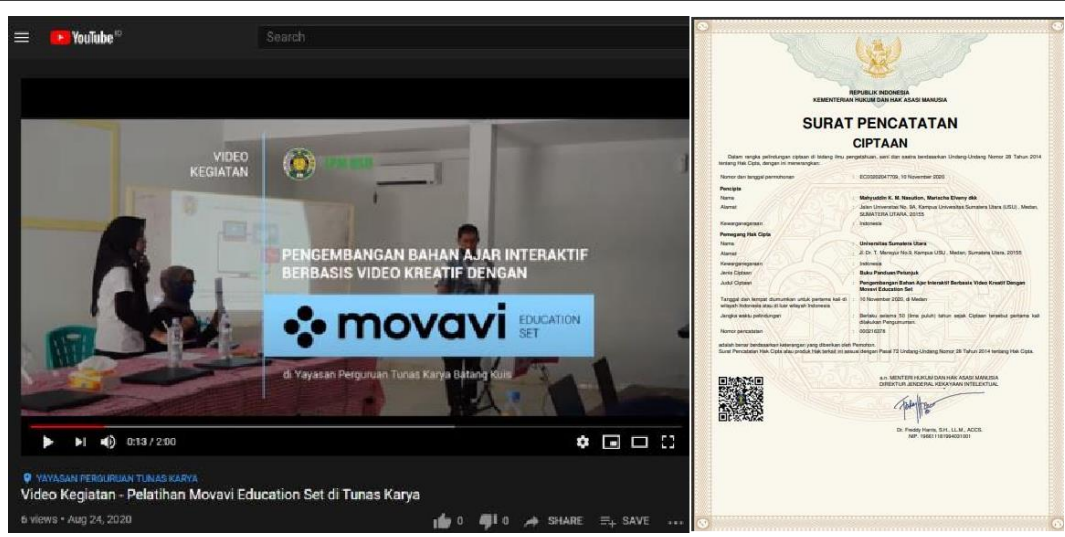

Gambar 3.2. Publikasi kegiatan di Youtube dan sertifikat hak cipta buku panduan

\section{KESIMPULAN}

Dari kegiatan pengabdian masyarakat yang telah dilakukan diperoleh kesimpulan sebagai berikut:

1. Respon positif dari pihak mitra terhadap kegiatan pengabdian ini dikarenakan hal ini merupakan salah satu permasalahan yang dimiliki oleh pihak mitra. Dengan adanya kegiatan pengabdian ini bisa memberikan solusi bagi mitra untuk menyelesaikan permasalahan yang ada.

2. Kegiatan ini meningkatkan kemampuan para guru di sekolah mitra sehingga ke depannya para guru mampu mengimplementasikan pelatihan yang diberikan di bidangnya masing-masing dan dapat mengikuti perkembangan zaman pada masa sekarang ini dimana proses pembelajaran dapat dibantu dengan menggunakan video sebagai salah satu media pembelajaran.

\section{UCAPAN TERIMAKASIH}

Artikel ini merupakan salah satu hasil dari Program Pengabdian kepada Masyarakat yang dibiayai oleh NON PNBP Universitas Sumatera Utara dengan nomor 287/UN5.2.3.2.1/PPM/2020. Oleh karena itu, tim pengabdian mengucapkan terima kasih kepada Lembaga Pengabdian Masyarakat (LPM) USU terutama kepada Rektor Universitas Sumatera Utara atas dukungan dana dan fasilitas yang diberikan. Terima kasih juga kepada mitra pada kegiatan pengabdian ini.

\section{DAFTAR PUSTAKA (REFERENCES)}

Chaeruman, U. Anis. (2018). Alur Belajar : Meningkatkan Interaktivitas Pembelajaran Daring. Seminar \& Lokakarya Pembelajaran Daring Di Perguruan Tinggi Gd. D. Lt. 2, Kemristekdikti, Jakarta.

Kuntarto, E. (2017). Keefektifan Model Pembelajaran Daring Dalam Perkuliahan Bahasa Indonesia di Perguruan Tinggi. Journal Indonesian Language Education and Literature, 3 (1), 99-110.

Rimbarizki, R. (2017). Penerapan Pembelajaran Daring Kombinasi dalam Meningkatkan Motivasi Belajar Peserta Didik Paket C Vokasi di Pusat Kegiatan Belajar Masyarakat (PKBM) Pioneer Karanganyar. J+Plus Unesa, 6 (2), 1-12. 